Check for updates

Cite this: RSC Adv., 2019, 9, 27593

Received 20th May 2019

Accepted 21st August 2019

DOI: $10.1039 / c 9 r a 03781 \mathrm{k}$

rsc.li/rsc-advances

\section{Enhanced dewaterability of waste activated sludge by a combined use of permanganate and peroxymonosulfate}

\author{
Lu Luo, ${ }^{a}$ Yongjian Ge, ${ }^{b}$ Shuyu Yuan, ${ }^{c}$ Yanghai $Y_{u}{ }^{a}$ Zhou Shi, $^{a}$ Shiqing Zhou ${ }^{\star a}$ \\ and Jing Deng (iD) *c
}

Ever-increasing efforts have been made to develop rapid and practical conditioning methods of sludge dewatering. This study demonstrated an innovative combination of potassium permanganate $\left(\mathrm{KMnO}_{4}\right)$ and peroxymonosulfate (PMS) for sludge dewatering. The combined use of $\mathrm{KMnO}_{4}$ and $\mathrm{PMS}\left(\mathrm{KMnO}_{4} / \mathrm{PMS}\right)$ showed its superiority in improving sludge dewaterability over the separate use of $\mathrm{KMnO}_{4}$ or PMS. By dosing $4 \mathrm{mmol} \mathrm{g}^{-1}$ VSS $\mathrm{KMnO}_{4}$ and $3 \mathrm{mmol} \mathrm{g}^{-1}$ VSS PMS, the dewaterability of waste activated sludge (WAS) significantly enhanced as capillary suction time (CST) decreased from $73.65 \mathrm{~s}$ to $24.65 \mathrm{~s}$ while the water content of dewatered sludge cake $\left(W_{C}\right)$ decreased from $78.96 \%$ to $70.47 \%$. Apart from CST and $W_{C}$, the $\mathrm{KMnO}_{4} / \mathrm{PMS}$ process could also affect negative zeta potential, sludge flocs size and the concentrations of protein and polysaccharide in extracellular polymeric substances (EPS). The enhanced sludge dewaterability and changes of the physicochemical characteristics of the WAS samples during the $\mathrm{KMnO}_{4} / \mathrm{PMS}$ process were actually ascribed to sulfate radicals $\left(\mathrm{SO}_{4}{ }^{-}\right)$and hydroxyl radicals $\left(\mathrm{HO} \mathrm{O}^{\circ}\right)$ in situ generated via $\mathrm{PMS}$ activation by manganese oxides $\left(\mathrm{MnO}_{x}\right)$ in the states of $\mathrm{MnO}_{2}$ and $\mathrm{Mn}_{3} \mathrm{O}_{4}$ transferred from $\mathrm{KMnO}_{4}$ oxidation, which was verified by transmission electron microscopy (TEM), energy dispersive X-ray spectroscopy (EDX) techniques and radical scavenging experiments. Moreover, the Fourier transform infrared spectroscopy (FTIR) analysis further confirmed that the in situ generated $\mathrm{SO}_{4}{ }^{-}$and $\mathrm{HO}$ could improve sludge dewaterability. Thus, the $\mathrm{KMnO}_{4} / \mathrm{PMS}$ process could be considered as a promising conditioning method of sludge dewatering.

\section{Introduction}

The management of large quantities of waste activated sludge (WAS) produced from activated sludge processes has posed great challenges to municipal wastewater treatment plants (WWTPs) due to great economic and environmental burden. ${ }^{\mathbf{1 - 4}}$ As reported, the treatment and disposal of excess sludge usually accounts for up to $60 \%$ of the total operating cost in WWTPs. ${ }^{2}$ Consequently, how to substantially cut down this kind of cost has become a significant issue, and many researchers and practitioners have tried their best to tackle this problem. WAS has a high water content in the form of free and bound water (over 90\%). ${ }^{5}$ And sludge dewatering has been generally considered as a promising strategy in reducing sludge volume and cost of sludge transport and ultimate disposal. ${ }^{3,4}$ However, the sludge dewatering process is usually inhibited due to the

\footnotetext{
${ }^{a}$ Key Laboratory of Building Safety and Energy Efficiency, Ministry of Education, Department of Water Engineering and Science, College of Civil Engineering, Hunan University, Changsha, Hunan 410082, P. R. China. E-mail: shiqingzhouwater@163. com

${ }^{b}$ China United Engineering Corporation Limited, Hangzhou 310052, P. R. China ${ }^{c}$ College of Civil Engineering and Architecture, Zhejiang University of Technology, Hangzhou 310014, P. R. China. E-mail: 1029877668@qq.com
}

presence of extracellular polymeric substances (EPS) that can retain a large amount of water, especially bound water. ${ }^{6,7}$ Hence, increasing efforts have been focused on development of efficient sludge dewatering techniques, which can promote the release of bound water from EPS. So far, thermal, ultrasonication, freezing and thawing, and chemical oxidation have been investigated to improve sludge dewaterability. ${ }^{7-12}$ Among all the developed methods, advanced oxidation processes (AOPs) have recently shown their superiority in sludge disintegration and dewatering.

AOPs usually rely on the produced highly reactive radical species, such as hydroxyl radicals ( $\left.\mathrm{HO}^{\circ}\right)$ and sulfate radicals $\left(\mathrm{SO}_{4}{ }^{-}\right)$to disrupt WAS and degrade EPS, thereby enhancing sludge dewaterability. ${ }^{\mathbf{2 , 1 3 , 1 4}}$ It has been reported that the Fenton (combination of $\mathrm{H}_{2} \mathrm{O}_{2}$ and $\mathrm{Fe}^{2+}$ ) and Fenton-like (e.g., simultaneous addition of $\mathrm{H}_{2} \mathrm{O}_{2}$ and $\mathrm{Fe}^{3+}$ ) processes based on $\mathrm{HO}^{*}$ production could efficiently improve the dewaterability of WAS. ${ }^{1,7}$ However, only under strongly acidic conditions $(\mathrm{pH}=2-$ 5) can these processes generate sufficient amounts of $\mathrm{HO}^{\bullet}$ for better sludge dewaterability, which significantly hindered the sludge dewatering process and subsequent disposal. ${ }^{15-17}$ Compared to $\mathrm{HO}^{-}\left(E^{0}=1.8-2.7 \mathrm{~V}\right), \mathrm{SO}_{4}{ }^{-}{ }^{-}$owns a higher redox potential $\left(E^{0}=2.5-3.1 \mathrm{~V}\right)$, a longer life time $(30-40 \mu \mathrm{s})$ and a wider working $\mathrm{pH}$ range $(\mathrm{pH} 4-9) .{ }^{4,18}$ Therefore, pretty much 
attention has been recently paid to the $\mathrm{SO}_{4}{ }^{-}$-based AOPs as new alternative methods of sludge conditioning. $\mathrm{SO}_{4}{ }^{-}$is usually generated through the activation of peroxydisulfate (PDS, $\mathrm{S}_{2} \mathrm{O}_{8}{ }^{2-}$ ) and peroxymonosulfate (PMS, $\mathrm{HSO}_{5}{ }^{-}$) by ultraviolet (UV), heat, base and (transition) metal catalysts. ${ }^{19-25}$

Our recent study investigated $\alpha-\mathrm{MnO}_{2}$ with different morphologies (nanoparticles, nanoflowers and nanorods) synthesized via a facile hydrothermal method as activators of PMS for ciprofloxacin (CIP) degradation, and found that $\alpha$ $\mathrm{MnO}_{2}$ nanoflowers achieved much higher degradation efficiency of CIP than the other three $\mathrm{MnO}_{2}\left(\alpha-\mathrm{MnO}_{2}\right.$ nanorods, $\alpha$ $\mathrm{MnO}_{2}$ nanoparticles and commercial $\mathrm{MnO}_{2}$ ), which would be attributed to its higher catalytic activity of PMS and larger quantities of $\mathrm{SO}_{4}{ }^{-}$produced from its activation of $\mathrm{PMS}^{26}$ Interestingly, Cui et al. recently studied chemical oxidation of benzene and trichloroethylene (TCE) by an innovative combined use of permanganate $\left(\mathrm{KMnO}_{4}\right)$ and PMS $\left(\mathrm{KMnO}_{4} /\right.$ PMS), and also found that it was mainly colloidal and amorphous $\mathrm{MnO}_{2}$ in situ generated from $\mathrm{KMnO}_{4}$ oxidation that activated PMS to trigger powerful $\mathrm{SO}_{4}{ }^{\cdot-}$-mediated oxidation of both benzene and TCE. ${ }^{27}$ As known to us all, both $\mathrm{KMnO}_{4}$ and PMS have been widely used as powerful oxidants to destruct organic pollutants in water and wastewater. Recently, the two powerful oxidants were also applied to enhance the filterability of waste activated sludge. ${ }^{28,29} \mathrm{Wu}$ et al. reported that $\mathrm{KMnO}_{4}$ could efficiently disintegrate the excess sludge with soluble chemical oxygen demand (SCOD) increasing by $3473 \%$, and that the optimal $\mathrm{KMnO}_{4} /$ sludge solid mass ratio was 0.1 with a stable disintegration degree $\left(\mathrm{DD}_{\mathrm{COD}}\right)$ of about $34 \%$ while suitable reaction time was $30 \mathrm{~min} .{ }^{28} \mathrm{Niu}$ et al. found that PMS oxidation could effectively break sludge particles, and that EPS increased significantly and transferred to slime layer after PMS treatment. ${ }^{29}$ Yang et al. also reported that PMS could facilitate the disintegration of WAS and the biodegradability of organics could be enhanced after treatment by PMS. ${ }^{30}$ Although it has been proven that $\mathrm{KMnO}_{4}$ and PMS could disintegrate WAS and enhance sludge dewaterability, the synergistic effect of both oxidants on the dewaterability of WAS still remains unknown.

In this paper, we proposed a combined use of $\mathrm{KMnO}_{4}$ and PMS ( $\mathrm{KMnO}_{4} / \mathrm{PMS}$ ) for sludge dewatering. The dewaterability of WAS during the $\mathrm{KMnO}_{4} / \mathrm{PMS}$ process by the measurement of variations in capillary suction time (CST) and water content of dewatered sludge cake $\left(W_{\mathrm{C}}\right)$ was initially investigated. Then, the physicochemical characteristics of WAS (CST, $W_{\mathrm{C}}$, zeta potential, particle size and the concentrations of protein and polysaccharide in EPS) at different dosages of $\mathrm{KMnO}_{4}$ and PMS were further studied. Finally, the mechanism of sludge dewatering by the $\mathrm{KMnO}_{4} / \mathrm{PMS}$ process was deeply explored.

\section{Materials and methods}

\subsection{Raw sludge and chemicals}

The raw sludge was collected from Qige municipal wastewater treatment plant in Hangzhou, China. A sieve with 20 mesh was then used to remove big gravels and debris from the collected sludge samples. The supernatant was finally decanted to acquire the denser sludge samples used in this study after plain sedimentation. The acquired denser sludge samples were stored at $4{ }^{\circ} \mathrm{C}$ in a refrigerator prior to use, and all the experiments were completed within $48 \mathrm{~h}$. The basic characteristics of the sludge samples were measured and shown in Table 1.

All the chemicals were used without further purification. Peroxymonosulfate (Oxone®, $\mathrm{KHSO}_{5} \cdot 0.5 \quad \mathrm{KHSO}_{4} \cdot 0.5 \quad \mathrm{~K}_{2} \mathrm{SO}_{4}$, $\mathrm{KHSO}_{5} \geq 47 \%$ ) was provided by Aladdin Co., Ltd. (Shanghai, China). Permanganate $\left(\mathrm{KMnO}_{4}, \geq 99.5 \%\right)$, sodium hydroxide $(\mathrm{NaOH}, \geq 96.0 \%)$, and sulfuric acid $\left(\mathrm{H}_{2} \mathrm{SO}_{4}, 95.0-98.0 \%\right)$ were supplied by Sinopharm Chemical Reagent Co., Ltd. (Shanghai, China).

\subsection{Experimental procedures}

All the sludge dewatering experiments were conducted in an Erlenmeyer flask with a volume of $500 \mathrm{~mL}$. In each test, $300 \mathrm{~mL}$ sludge sample was added and then mixed with a stoichiometric amount of PMS. When PMS was completely dissolved under thorough stirring, $\mathrm{H}_{2} \mathrm{SO}_{4}$ or $\mathrm{NaOH}$ was used to adjust the solution $\mathrm{pH}$ to 7 . Finally, the reaction was immediately initiated by dosing a calculated amount of $\mathrm{KMnO}_{4}$ in a water bath apparatus (300 rpm), and was ceased after $120 \mathrm{~min}$. All the experiments were duplicated at least, and the average values with standard deviations were presented.

\subsection{Analytical methods}

2.3.1. CST and $\boldsymbol{W}_{\mathbf{C}}$ determination. The dewaterability of WAS is commonly evaluated by CST and $W_{\mathrm{C}}$. CST was measured using a CST instrument (Type 304, Triton Ltd., UK) equipped with an $18 \mathrm{~mm}$ diameter funnel and a standard Whatman no. 17 chromatography-grade paper. To determine $W_{\mathrm{C}}$, the sludge samples were pretreated by a vacuum filtration method. Briefly, $50 \mathrm{~mL}$ sludge sample was poured into a standard Buchner funnel and filtered at a constant vacuum pressure for $15 \mathrm{~min}$. The water content of the vacuum-filtered sludge cake trapped by the filter paper was measured according to the standard method, and calculated according to eqn (1):

$$
W_{\mathrm{C}}=\frac{m_{2}-m_{3}}{m_{2}-m_{1}} \times 100 \%
$$

where $m_{1}$ is the weight of the filter paper, $m_{2}$ is the weight of the vacuum-filtered sludge cake, and $m_{3}$ is the weight of the vacuum-filtered sludge cake completely dried at $105^{\circ} \mathrm{C}$.

2.3.2. EPS extraction and analysis. EPS were extracted using a heat extraction method described by Yu et al. ${ }^{6}$ Briefly, 50 $\mathrm{mL}$ sludge sample was centrifuged at $4000 \mathrm{~g}$ for $5 \mathrm{~min}$ at $4{ }^{\circ} \mathrm{C}$ to acquire the supernatant as soluble EPS (S-EPS). The sludge pellets were then diluted with a $0.05 \mathrm{w} / \mathrm{v} \% \mathrm{NaCl}$ solution that

Table 1 Basic characteristics of sludge samples

\begin{tabular}{llc}
\hline Parameter & Unit & \multicolumn{1}{l}{ Value } \\
\hline $\mathrm{pH}$ & - & $6.85 \pm 0.05$ \\
Water content & $\%$ & $96.205 \pm 0.005$ \\
Volatile suspended solids (VSS) & $\mathrm{g} \mathrm{L}^{-1}$ & $30.364 \pm 0.394$ \\
Total suspended solids (TSS) & $\mathrm{g} \mathrm{L}^{-1}$ & $39.133 \pm 0.951$ \\
VSS/TSS & $\%$ & $77.355 \pm 0.875$ \\
CST & $\mathrm{S}$ & $73.65 \pm 1.45$
\end{tabular}


was pre-heated to $70{ }^{\circ} \mathrm{C}$. The diluted sludge solution was immediately sheared by a vortex mixer for 1 min and centrifuged at $4000 \mathrm{~g}$ for $10 \mathrm{~min}$ at $4{ }^{\circ} \mathrm{C}$ to collect the supernatant as the loosely bound EPS (LB-EPS). The residual sludge pellets were resuspended in a $0.05 \mathrm{w} / \mathrm{v} \% \mathrm{NaCl}$ solution and heated to $60{ }^{\circ} \mathrm{C}$ in a water bath for $30 \mathrm{~min}$. At short notice, the resuspended sludge solution was centrifuged at $4000 \mathrm{~g}$ for $15 \mathrm{~min}$ at 4 ${ }^{\circ} \mathrm{C}$, and the supernatant was collected as the tightly bound EPS (TB-EPS).

Before the analyses of protein and polysaccharide (assumed as dominant components of EPS), the EPS samples were pretreated with an optimal amount of $\mathrm{Na}_{2} \mathrm{SO}_{3}$ to quench the residual colored $\mathrm{KMnO}_{4}$. The pretreated EPS sample was then filtered through a $0.45 \mu \mathrm{m}$ cellulose acetate membrane. The protein content was quantified by the modified Lowry-Folin method using bovine serum albumin as the standard. ${ }^{31}$ The polysaccharide content was determined by the phenol-sulfuric acid method using glucose as the standard. ${ }^{32}$

2.3.3. Other analyses. The zeta potential of the WAS samples was analyzed using a Zetasizer Nano (Nano-ZS90, Malvern Instrument Ltd., UK). The particle size distribution was measured by a laser particle size analyzer (LAP-W2000H) using ultrapure water as the dispersant. The Fourier transform infrared spectroscopy (FTIR) analysis of sludge samples was recorded in a wavenumber range of $4000-400 \mathrm{~cm}^{-1}$ by a Nicolet 6700 spectrometer (Thermo, USA).

Given the difficulty in separating the formed solids from the conditioned WAS samples, the extracted EPS solution was used and treated with the $\mathrm{KMnO}_{4} / \mathrm{PMS}$ process to monitor whether manganese oxides $\left(\mathrm{MnO}_{x}\right)$ formed after $\mathrm{KMnO}_{4}$ oxidation of the organics in EPS. Briefly, after the extracted EPS solution was treated with the $\mathrm{KMnO}_{4} / \mathrm{PMS}$ process, the reaction solution was filtered through a $0.45 \mu \mathrm{m}$ cellulose acetate membrane to collect the brown-red solids. Then, the collected solids were rinsed alternately several times using ethanol and ultrapure water, and vacuum-dried at $60{ }^{\circ} \mathrm{C}$ overnight. Finally, the dried solid samples were scanned by transmission electron microscopy (TEM) to capture the microscale crystallization and structure and energy dispersive X-ray spectroscopy (EDX) to analyze the elemental composition.

\section{Results and discussion}

\subsection{Feasibility of sludge dewatering with the $\mathrm{KMnO}_{4} / \mathrm{PMS}$ process}

Fig. 1 compared the dewaterability of the WAS samples conditioned by $\mathrm{KMnO}_{4}$ alone, PMS alone, and a combination of $\mathrm{KMnO}_{4}$ and PMS $\left(\mathrm{KMnO}_{4} / \mathrm{PMS}\right)$, respectively. As observed, the CST increased from $73.65 \mathrm{~s}$ to $140.60 \mathrm{~s}$ and $278.55 \mathrm{~s}$, respectively when the WAS samples were conditioned by $7 \mathrm{mmol} \mathrm{g}^{-1}$ VSS PMS and $\mathrm{KMnO}_{4}$ alone, respectively, which indicated that neither PMS alone nor $\mathrm{KMnO}_{4}$ alone could efficiently improve the sludge dewaterability, and that the two individuals even worsened the dewaterability. The deterioration of sludge dewaterability was likely resulted from the progressive cell lysis and further releasing of intracellular biopolymers under the influence of $\mathrm{KMnO}_{4}$ or PMS when the intracellular biopolymers

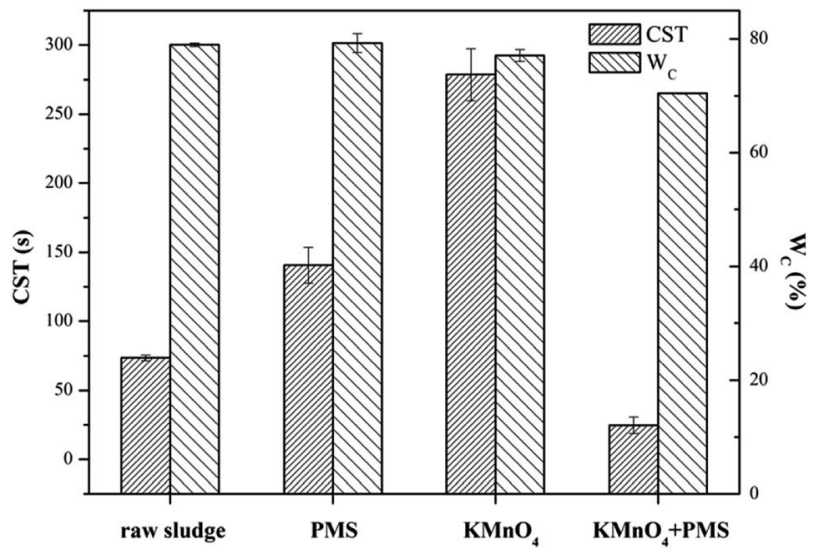

Fig. 1 Dewaterability change in the WAS samples conditioned by different methods (experimental conditions: $\left[\mathrm{KMnO}_{4}\right]=[\mathrm{PMS}]=7$ $\mathrm{mmol} \mathrm{g}{ }^{-1}$ VSS, $\left[\mathrm{KMnO}_{4}\right]+[\mathrm{PMS}]=4 \mathrm{mmol} \mathrm{g}{ }^{-1} \mathrm{VSS}+3 \mathrm{mmol} \mathrm{g}{ }^{-1}$ VSS, $\mathrm{pH}_{0}=7, T=25^{\circ} \mathrm{C}$ ).

could not be degraded effectively in current condition. ${ }^{33}$ Lee et al. also found that the PMS conditioning could deteriorate the dewaterability after the WAS samples were treated with different dosages of PMS at room temperature. ${ }^{5}$ Surprisingly, a combined use of $4 \mathrm{mmol} \mathrm{g}^{-1}$ VSS $\mathrm{KMnO}_{4}$ and $3 \mathrm{mmol} \mathrm{g}^{-1}$ VSS PMS instantly decreased the CST from $73.65 \mathrm{~s}$ to $24.65 \mathrm{~s}$, and apparently showed its synergistic effect on significantly improving the sludge dewaterability. Besides, the decrease of $W_{\mathrm{C}}$ (from $78.96 \%$ to $70.47 \%$ ) also indicated the synergistic effect after the WAS samples were conditioned by the $\mathrm{KMnO}_{4} / \mathrm{PMS}$ process while the $W_{\mathrm{C}}$ values almost remained unchanged after the samples were treated with PMS alone and $\mathrm{KMnO}_{4}$ alone (79.25\% and $77.07 \%$, respectively). The synergistic effect of the $\mathrm{KMnO}_{4} / \mathrm{PMS}$ process on the WAS dewaterability was interpreted with the decrease of both CST and $W_{\mathrm{C}}$, which also implied the generation of $\mathrm{SO}_{4}{ }^{-{ }^{-}}$and $\mathrm{HO}{ }^{\circ}$ during the $\mathrm{KMnO}_{4} / \mathrm{PMS}$ process as mentioned in Section 1.

\subsection{Effect of the $\mathrm{KMnO}_{4} / \mathrm{PMS}$ process on the physicochemical characteristics of the WAS samples}

3.2.1. Capillary suction time (CST). The dewaterability of the WAS samples were further investigated by simultaneously dosing different amounts of $\mathrm{KMnO}_{4}$ and PMS. As shown in Fig. 2, when PMS dosage was fixed at $1 \mathrm{mmol} \mathrm{g}^{-1} \mathrm{VSS}$, the increase of $\mathrm{KMnO}_{4}$ dosage from $2 \mathrm{mmol} \mathrm{g}^{-1}$ VSS to $6 \mathrm{mmol} \mathrm{g}^{-1}$ VSS did not decrease the CST, and instead jeopardized the dewaterability, which indicated the absence of the synergistic effect of the $\mathrm{KMnO}_{4} / \mathrm{PMS}$ process at a low PMS dosage. This might be because the in situ generated $\mathrm{SO}_{4}{ }^{-{ }^{-}}$and $\mathrm{HO}^{\circ}$ during the $\mathrm{KMnO}_{4} / \mathrm{PMS}$ process was too few to improve the dewaterability of the WAS samples when PMS dosage was too low. However, increasing PMS dosage to $2 \mathrm{mmol} \mathrm{g}^{-1}$ VSS efficiently enhanced the dewaterability, and the CST decreased from 73.65 $\mathrm{s}$ to $54.30 \mathrm{~s}, 46.45 \mathrm{~s}$ and $63.45 \mathrm{~s}$, respectively with increasing $\mathrm{KMnO}_{4}$ dosage from $2 \mathrm{mmol} \mathrm{g}^{-1}$ VSS to $6 \mathrm{mmol} \mathrm{g}^{-1}$ VSS. When PMS dosage continuously increased to $5 \mathrm{mmol} \mathrm{g}^{-1}$ VSS, the CST decreased to $22.45 \mathrm{~s}, 23.85 \mathrm{~s}$ and $22.00 \mathrm{~s}$, respectively as $\mathrm{KMnO}_{4}$ dosage increased from $2 \mathrm{mmol} \mathrm{g}^{-1}$ VSS to $6 \mathrm{mmol} \mathrm{g}^{-1}$ VSS. This 


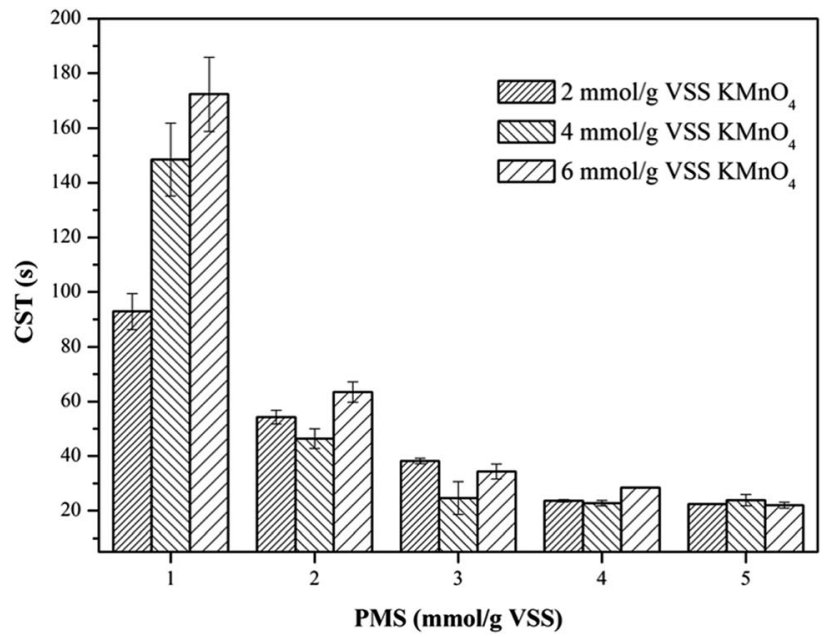

Fig. 2 Effect of the $\mathrm{KMnO}_{4} / \mathrm{PMS}$ process on CST of the WAS samples (experimental conditions: $\left[\mathrm{KMnO}_{4}\right]=2-6 \mathrm{mmol} \mathrm{g}^{-1}$ VSS, [PMS] $=1-5$ mmol g ${ }^{-1} \mathrm{VSS}, \mathrm{pH}_{0}=7, T=25^{\circ} \mathrm{C}$ ).

is because the higher PMS dosage, the more $\mathrm{SO}_{4}{ }^{-}$and $\mathrm{HO}^{\circ}$ generated to achieve better sludge dewaterability. ${ }^{34}$ The similar results were also reported by Liu et al. when the $\mathrm{Fe}^{2+}$-activated PMS was used for sludge conditioning. ${ }^{4}$ Remarkably, the CST values did not decrease all the way, and instead decreased firstly and then increased with sustainably increasing $\mathrm{KMnO}_{4}$ dosage, which might be ascribed to the consumption of the generated $\mathrm{SO}_{4}{ }^{--}$and $\mathrm{HO}^{\circ}$ by $\mathrm{KMnO}_{4}$ with a too high dosage. ${ }^{35}$ Liu et al. also observed the similar results when using the magnetic $\mathrm{Fe}_{3} \mathrm{O}_{4}-\mathrm{MnO}_{2}$ core-shell nanocomposites-activated PMS for 4chlorophenol degradation. ${ }^{36}$

3.2.2. Water content of dewatered sludge cake $\left(W_{\mathrm{C}}\right)$. The profiles of $W_{\mathrm{C}}$ of the WAS samples after conditioning of the $\mathrm{KMnO}_{4} / \mathrm{PMS}$ process with different $\mathrm{KMnO}_{4}$ and PMS dosages were depicted in Fig. 3. As can be seen, the $W_{\mathrm{C}}$ changes in the WAS samples were quite similar to the CST changes discussed in Section 3.2.1. By dosing $1 \mathrm{mmol} \mathrm{g}^{-1}$ VSS PMS, the $W_{\mathrm{C}}$ after conditioning with $2 \mathrm{mmol} \mathrm{g}^{-1} \mathrm{VSS}, 4 \mathrm{mmol} \mathrm{g}^{-1}$ VSS and $6 \mathrm{mmol}$ $\mathrm{g}^{-1}$ VSS $\mathrm{KMnO}_{4}$, respectively $(82.11 \%, 76.73 \%$ and $77.56 \%)$ almost remained unchanged, compared to the $W_{\mathrm{C}}$ of the raw sludge (78.96\%). This suggested that the synergistic effect of the $\mathrm{KMnO}_{4} / \mathrm{PMS}$ process with $1 \mathrm{mmol} \mathrm{g}^{-1}$ VSS PMS would not work. However, the $W_{\mathrm{C}}$ of the WAS samples would continue to decrease with the ever-increasing PMS dosages, which was also attributed to more $\mathrm{SO}_{4}{ }^{--}$and $\mathrm{HO}^{\circ}$ generated from the $\mathrm{KMnO}_{4} /$ PMS process. The $W_{\mathrm{C}}$ after conditioning could decrease to about $67.5 \%$, and by $11.46 \%$ compared to the $W_{\mathrm{C}}$ of the raw sludge, which was higher than the variation in the $W_{\mathrm{C}}$ of the WAS samples conditioned by the Fenton-like process $(8.7 \%){ }^{1}$

3.2.3. Zeta potential. To deeply investigate the effect of the $\mathrm{KMnO}_{4} / \mathrm{PMS}$ process on the WAS dewaterability, the zeta potentials of the WAS samples before and after conditioning were also measured. The unconditioned raw sludge was negatively charged with the zeta potential of $-17.7 \mathrm{mV}$, which was due to the ionization of the carboxyl and amino in the protein of EPS. ${ }^{37}$ It can be obviously observed from Fig. 4 that the zeta potentials of the WAS samples were affected by dosing either

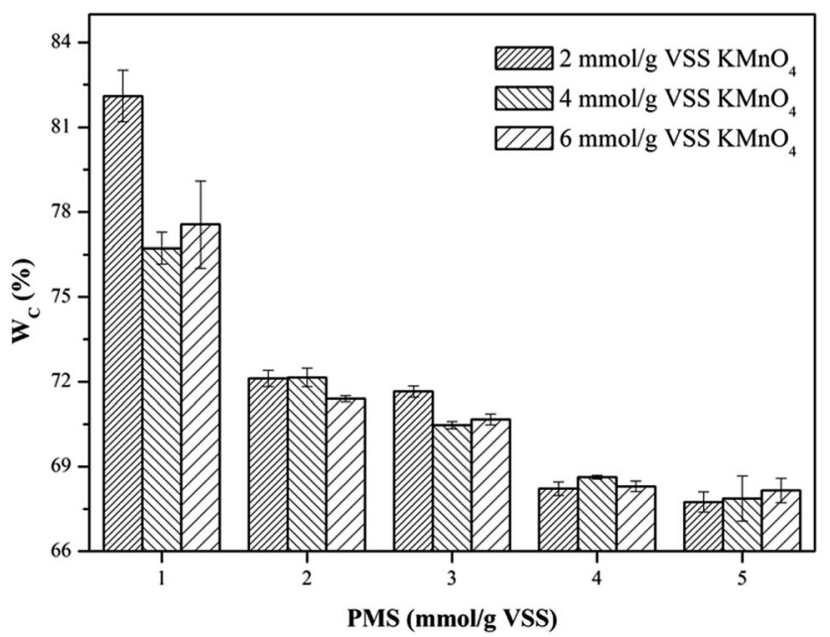

Fig. 3 Effect of the $\mathrm{KMnO}_{4} / \mathrm{PMS}$ process on $W_{\mathrm{C}}$ of the WAS samples (experimental conditions: $\left[\mathrm{KMnO}_{4}\right]=2-6 \mathrm{mmol} \mathrm{g}^{-1} \mathrm{VSS}$, [PMS] $=1-5$ mmol g ${ }^{-1}$ VSS, $\mathrm{pH}_{0}=7, T=25^{\circ} \mathrm{C}$ ).

$\mathrm{KMnO}_{4}$ or PMS. The zeta potential tended to increase to $0 \mathrm{mV}$ with increasing $\mathrm{KMnO}_{4}$ or PMS dosage. By simultaneously dosing $4 \mathrm{mmol} \mathrm{g}^{-1}$ VSS $\mathrm{KMnO}_{4}$ and $5 \mathrm{mmol} \mathrm{g}^{-1}$ VSS PMS, the zeta potential increased to $-2.15 \mathrm{mV}$. The increase in the zeta potential suggested the ever-increasing sludge dewaterability, which quite matched with the changes of the CST and $W_{\mathrm{C}}$. Zhen et al. also reported that the sludge dewaterability improved as the zeta potential increased in the $\mathrm{Fe}^{2+}$-activated persulfate process. ${ }^{38}$ According to the DLVO theory, the aggregation of sludge flocs is mainly controlled by the surface charge. The decrease in the negative surface charge of sludge flocs would reduce the electrostatic repulsion and bring about the increment of interaction energy, which led to the aggregation of sludge flocs and finally enhanced sludge dewaterability. Therefore, it can be concluded that sludge flocs are easier for agglomeration and sedimentation, and thus dewatering as the zeta potential increases. ${ }^{39}$

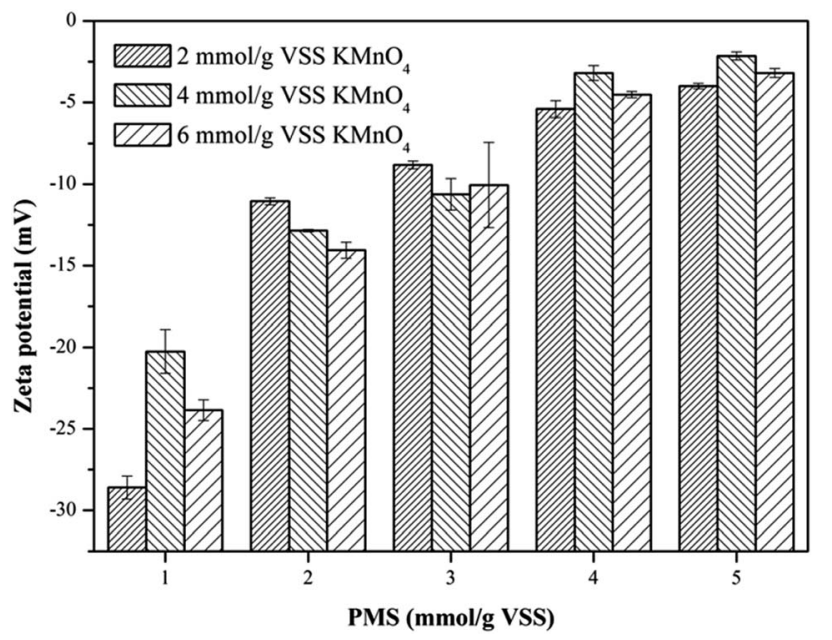

Fig. 4 Effect of the $\mathrm{KMnO}_{4} / \mathrm{PMS}$ process on zeta potential of the WAS samples (experimental conditions: $\left[\mathrm{KMnO}_{4}\right]=2-6 \mathrm{mmol} \mathrm{g}^{-1} \mathrm{VSS}$, $[P M S]=1-5 \mathrm{mmol} \mathrm{g}^{-1} \mathrm{VSS}, \mathrm{pH}_{0}=7, T=25^{\circ} \mathrm{C}$ ). 
3.2.4. Particle size distribution. As depicted in Fig. 5, effect of the $\mathrm{KMnO}_{4} / \mathrm{PMS}$ process on particle size distribution of the WAS samples was also investigated. The $D_{50}$ value of the unconditioned sludge flocs was determined to be $39.2 \mu \mathrm{m}$. When the WAS samples were conditioned with $2 \mathrm{mmol} \mathrm{g}^{-1}$ VSS $\mathrm{KMnO}_{4}$ and $1 \mathrm{mmol} \mathrm{g}^{-1}$ VSS PMS, the $D_{50}$ value decreased to $32.95 \mu \mathrm{m}$. With PMS dosage increasing to $5 \mathrm{mmol} \mathrm{g}^{-1} \mathrm{VSS}$, the $D_{50}$ value also decreased to $30.08 \mu \mathrm{m}$. By dosing $4 \mathrm{mmol} \mathrm{g}^{-1} \mathrm{VSS}$ and $6 \mathrm{mmol} \mathrm{g}^{-1}$ VSS $\mathrm{KMnO}_{4}$, the $D_{50}$ values of the conditioned sludge flocs decreased from $30.42 \mu \mathrm{m}$ and $28.35 \mu \mathrm{m}$ to $25.78 \mu \mathrm{m}$ and $24.44 \mu \mathrm{m}$, respectively with increasing PMS dosage. Therefore, increasing both $\mathrm{KMnO}_{4}$ and PMS dosages could reduce the size of the conditioned sludge flocs. The decrease of the sludge flocs size suggested that the $\mathrm{KMnO}_{4} / \mathrm{PMS}$ process could efficiently break the sludge flocs to enhance the sludge dewaterability as the flocs breakage could provide more passages for the removal of water in the inner of sludge flocs. ${ }^{40}$ It was also reported by Higgins and Novak that the sludge dewaterability was adversely impacted by the flocs in the range of 1-100 $\mu \mathrm{m}$ and decreased as the quantities of flocs in this size range increased. ${ }^{\mathbf{4 1}}$

3.2.5. Extracellular polymeric substances (EPS). EPS can have significant effects on the compressibility of sludge and the ability to bind water molecules of sludge flocs, and thus the dewaterability of sludge. ${ }^{42}$ Since EPS are mainly composed of protein and polysaccharide, variations in the concentrations of protein and polysaccharide in different EPS fractions (S-EPS,
LB-EPS and TB-EPS) were monitored to reveal why the $\mathrm{KMnO}_{4} /$ PMS process could improve sludge dewaterability. As illustrated in Fig. 6a, with the increase of PMS dosage, the protein content in total EPS tended to decrease. By dosing $2 \mathrm{mmol} \mathrm{g}^{-1} \mathrm{VSS}$ $\mathrm{KMnO}_{4}$, the protein content in total EPS decreased from 53.46 $\mathrm{mg} \mathrm{g}^{-1}$ VSS to $36.99 \mathrm{mg} \mathrm{g}^{-1}$ VSS while the protein content in SEPS increased from $21.57 \mathrm{mg} \mathrm{g}^{-1}$ VSS to $29.31 \mathrm{mg} \mathrm{g}^{-1}$ VSS before decreasing to $21.59 \mathrm{mg} \mathrm{\textrm {g } ^ { - 1 }}$ VSS, as PMS dosage increased. Moreover, the protein content in LB-EPS decreased from $25.21 \mathrm{mg} \mathrm{g}^{-1}$ VSS to $9.01 \mathrm{mg} \mathrm{g}^{-1}$ VSS while the protein content in TB-EPS decreased from $9.68 \mathrm{mg} \mathrm{g}^{-1}$ VSS to $6.39 \mathrm{mg}$ $\mathrm{g}^{-1}$ VSS. Similar changes of the protein content in total EPS, SEPS, LB-EPS and TB-EPS could also be observed when $4 \mathrm{mmol}$

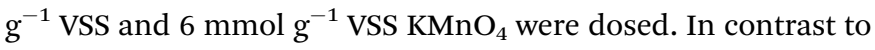
Fig. $6 \mathrm{a}$ and $\mathrm{b}$ showed that changes of the polysaccharide and protein content in EPS resembled each other.

The dissolved organics (protein and polysaccharide) in S-EPS increased before decreasing because TB-EPS were dissolved and transferred to S-EPS after the sludge flocs were destructed by $\mathrm{SO}_{4}{ }^{--}$and $\mathrm{HO}^{\circ}$ generated in the $\mathrm{KMnO}_{4} / \mathrm{PMS}$ process. ${ }^{29}$ Nevertheless, more $\mathrm{SO}_{4}{ }^{-}$and $\mathrm{HO}^{\circ}$ were generated to degrade the organics in S-EPS when PMS dosage continued to increase, so the protein and polysaccharide content in S-EPS tended to decrease. In addition, the slump of the protein and polysaccharide content in S-EPS, LB-EPS and TB-EPS accounted for $\mathrm{SO}_{4}{ }^{-}$and $\mathrm{HO}^{-}$generation in the $\mathrm{KMnO}_{4} / \mathrm{PMS}$ process and its high reactivity toward S-EPS, LB-EPS, and even TB-EPS. ${ }^{4}$
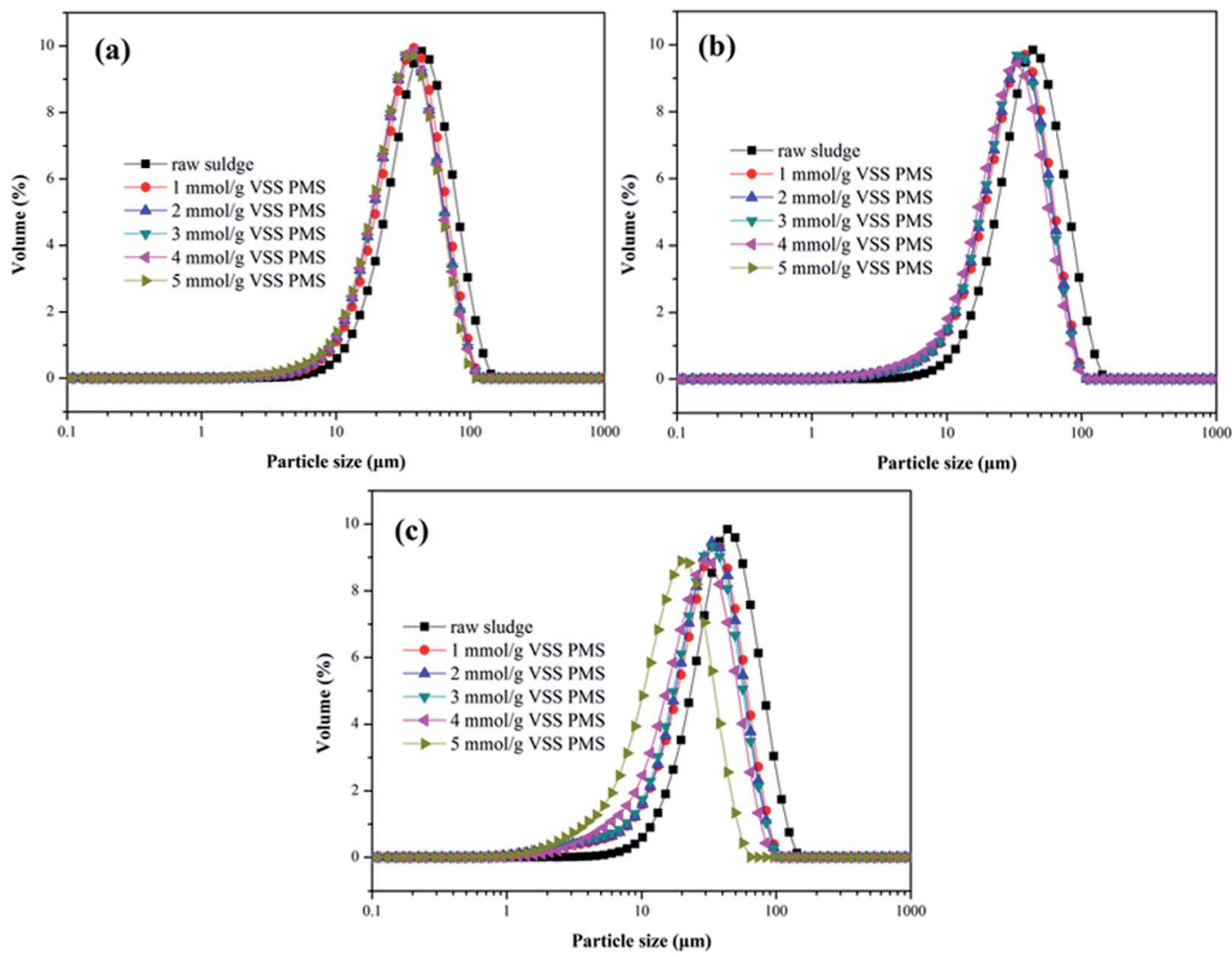

Fig. 5 Effect of the $\mathrm{KMnO}_{4} / \mathrm{PMS}$ process on particle size distribution of the WAS samples: (a) $2 \mathrm{mmol} \mathrm{g}^{-1} \mathrm{VSS} \mathrm{KMnO}_{4}$; (b) $4 \mathrm{mmol} \mathrm{g}^{-1} \mathrm{VSS} \mathrm{KMnO}_{4}$; (c) $6 \mathrm{mmol} \mathrm{g}^{-1} \mathrm{VSS} \mathrm{KMnO}_{4}$ (experimental conditions: $[\mathrm{PMS}]=1-5 \mathrm{mmol} \mathrm{g}^{-1} \mathrm{VSS}, \mathrm{pH}_{0}=7, T=25^{\circ} \mathrm{C}$ ). 

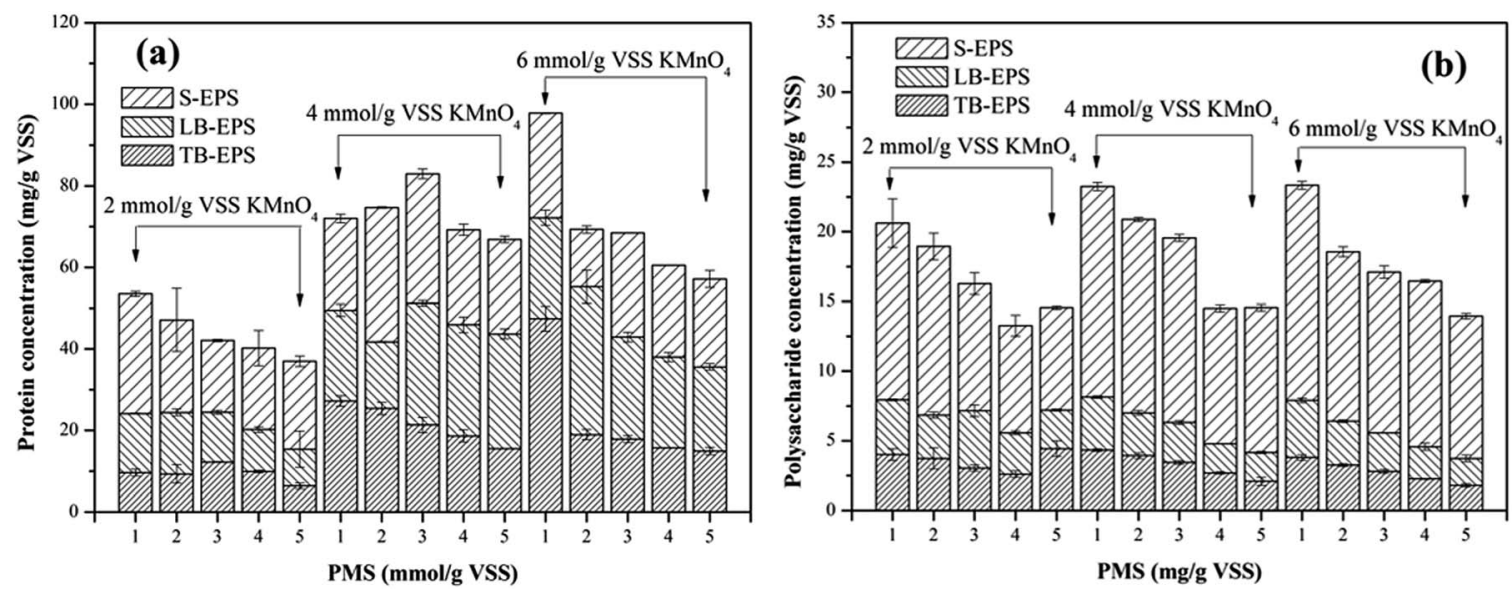

Fig. 6 Effect of the $\mathrm{KMnO}_{4} / \mathrm{PMS}$ process on EPS of the WAS samples: (a) protein; (b) polysaccharide (experimental conditions: [KMnO 4 ] $=2-6$ $\mathrm{mmol} \mathrm{g}{ }^{-1}$ VSS, [PMS] $=1-5 \mathrm{mmol} \mathrm{g}^{-1}$ VSS, $\mathrm{pH}_{0}=7, T=25^{\circ} \mathrm{C}$ ).

\subsection{Mechanism of WAS dewatering by the $\mathrm{KMnO}_{4} / \mathrm{PMS}$ process}

Due to the versatility and efficiency, $\mathrm{KMnO}_{4}$ was deemed as an important precursor for the fabrication of manganese oxide nanomaterials through chemical reduction, including manganese dioxides, tetraoxides and oxyhydroxides. ${ }^{43} \mathrm{Wu}$ et al. used $\mathrm{KMnO}_{4}$ as a conditioner for disintegration of excess activated sludge, and found that after sludge oxidation $\mathrm{KMnO}_{4}$ mainly transferred to the states of $\mathrm{MnO}_{2}$ and $\mathrm{Mn}_{3} \mathrm{O}_{4}$ while some compounds of $\mathrm{K}_{x} \mathrm{MnO}_{4}$ also existed in the solids. ${ }^{28}$ Due to the multivalent nature of $\mathrm{Mn}, \mathrm{MnO}_{2}$ and $\mathrm{Mn}_{3} \mathrm{O}_{4}$ have been proven to possess a high catalytic activity toward $\mathrm{PMS}$ for $\mathrm{SO}_{4}{ }^{--}$ generation. ${ }^{\mathbf{4 4 5}}$ Thus, in the $\mathrm{KMnO}_{4} / \mathrm{PMS}$ process, manganese oxides $\left(\mathrm{MnO}_{x}\right)$ in the state of $\mathrm{MnO}_{2}$ and $\mathrm{Mn}_{3} \mathrm{O}_{4}$ might be generated from the reduction of $\mathrm{KMnO}_{4}$, then $\mathrm{MnO}_{2}$ and $\mathrm{Mn}_{3} \mathrm{O}_{4}$ further activated PMS to produce $\mathrm{SO}_{4}{ }^{-}$and $\mathrm{HO}^{\circ}$.

In order to verify the hypothesis, the formed solids were separated from the $\mathrm{KMnO}_{4} / \mathrm{PMS}$ process. And the samples were observed through TEM and EDX. From Fig. 7a-d, it could be clearly seen that some nanoscale solids did form in the $\mathrm{KMnO}_{4} /$ PMS process. Moreover, the EDX analysis further confirmed that the formed solids were mainly composed of element $\mathrm{Mn}, \mathrm{O}$ and $\mathrm{K}$ (Fig. 7e), and the weight percentages of $\mathrm{Mn}, \mathrm{O}$ and $\mathrm{K}$ were recorded to be $20.9 \%, 74.26 \%$ and $4.82 \%$. It suggested that $\mathrm{KMnO}_{4}$ was disintegrate into $\mathrm{MnO}_{x}$ under the influence of EPS. According to the previous study, the solids might also be $\mathrm{MnO}_{x}$ in the states of $\mathrm{MnO}_{2}, \mathrm{Mn}_{3} \mathrm{O}_{4}$ and $\mathrm{K}_{x} \mathrm{MnO}_{4} \cdot{ }^{28}$ Meanwhile, scavenging experiments using ethanol (EtOH) and tert-butyl alcohol (TBA) as radical scavengers were conducted to confirm the formation of $\mathrm{SO}_{4}{ }^{-}$and $\mathrm{HO}{ }^{*}$ in the $\mathrm{KMnO}_{4} / \mathrm{PMS}$ process. As can be seen in Fig. 8, after extra addition of $300 \mathrm{mmol} \mathrm{g}^{-1}$ VSS EtOH and TBA, the CST decreased from $73.65 \mathrm{~s}$ to $38.50 \mathrm{~s}$ and $30.25 \mathrm{~s}$, respectively while decreasing from 73.65 to $24.65 \mathrm{~s}$ without addition of any radical scavenger. Moreover, the reduction value of CST with the addition of EtOH was higher than that with the addition of TBA. Such difference in CST value drop by the two radical scavengers implied that both $\mathrm{SO}_{4}{ }^{-}$and $\mathrm{HO}^{\circ}$ were generated in the $\mathrm{KMnO}_{4} / \mathrm{PMS}$ process because EtOH can effectively quench both $\mathrm{SO}_{4}{ }^{--}$and $\mathrm{HO}^{\circ}$ while TBA reacts much faster with $\mathrm{HO}^{\circ}$ than $\mathrm{SO}_{4}{ }^{-{ }^{-25}}$
Based on both the results above and current studies, a possible mechanism was proposed. As depicted in Fig. 9, Firstly, $\mathrm{KMnO}_{4}$ transformed into $\mathrm{MnO}_{2}, \mathrm{Mn}_{3} \mathrm{O}_{4}$ and $\mathrm{K}_{x} \mathrm{MnO}_{4}$ after oxidizing the organics in EPS. Then, the in situ generated $\mathrm{MnO}_{2}$ and $\mathrm{Mn}_{3} \mathrm{O}_{4}$ efficiently activated PMS to generate $\mathrm{SO}_{4}{ }^{-}$ and $\mathrm{HO}^{\circ}$ (eqn (2)-(5)). In detail, $\mathrm{HSO}_{5}{ }^{-}$(the species of PMS) initially integrated with $\equiv \mathrm{Mn}^{\mathrm{IV}}$ and $\equiv \mathrm{Mn}^{\mathrm{III}}$ located at the surface of $\mathrm{MnO}_{2}$ and $\mathrm{Mn}_{3} \mathrm{O}_{4}$ by surface hydroxyl groups (eqn (6)). Then, $\equiv \mathrm{Mn}^{\mathrm{IV}}$ and $\equiv \mathrm{Mn}^{\mathrm{III}}$ would be reduced to $\equiv \mathrm{Mn}^{\mathrm{III}}$ and $\equiv \mathrm{Mn}^{\mathrm{II}}$, respectively with the generation of $\mathrm{SO}_{5}{ }^{-}$(eqn (7)). Meanwhile, the formed $\equiv \mathrm{Mn}^{\mathrm{III}}$ and $\equiv \mathrm{Mn}^{\mathrm{II}}$ could be oxidized to $\equiv \mathrm{Mn}^{\mathrm{IV}}$ and $\equiv \mathrm{Mn}^{\mathrm{III}}$ with the formation of $\mathrm{SO}_{4}{ }^{--}$(eqn (8) and (9)). Furthermore, $\mathrm{HO}^{\circ}$ could also be produced through the reaction between $\mathrm{SO}_{4}{ }^{--}$and $\mathrm{H}_{2} \mathrm{O}$ (eqn (5)). ${ }^{46}$ Finally, $\mathrm{SO}_{4}{ }^{\cdot-}$ and $\mathrm{HO}^{*}$ degraded the organics in EPS to break the sludge flocs so that huge quantities of bound water were released and became free water, thus significantly enhancing sludge dewaterability.

$$
\begin{aligned}
& 2 \mathrm{Mn}_{3} \mathrm{O}_{4}+\mathrm{HSO}_{5}{ }^{-} \rightarrow 3 \mathrm{Mn}_{2} \mathrm{O}_{3}+\mathrm{SO}_{4}{ }^{--}+\mathrm{H}^{+} \\
& 2 \mathrm{MnO}_{2}+\mathrm{HSO}_{5}^{-} \rightarrow \mathrm{SO}_{5}{ }^{--}+\mathrm{OH}^{-}+\mathrm{Mn}_{2} \mathrm{O}_{3} \\
& \mathrm{Mn}_{2} \mathrm{O}_{3}+\mathrm{HSO}_{5}^{-} \rightarrow \mathrm{SO}_{4}^{\cdot-}+2 \mathrm{MnO}_{2}+\mathrm{H}^{+} \\
& \mathrm{SO}_{4}{ }^{\cdot-}+\mathrm{H}_{2} \mathrm{O} \rightarrow \mathrm{HO}^{\cdot}+\mathrm{H}^{+}+\mathrm{SO}_{4}{ }^{2-} \\
& \equiv \mathrm{Mn}^{\mathrm{IV}(\mathrm{III})}-\mathrm{OH}+\mathrm{HSO}_{5}{ }^{-} \\
& \rightarrow \equiv \mathrm{Mn}^{\mathrm{IV}(\mathrm{III})}-(\mathrm{O}) \mathrm{OSO}_{3}{ }^{-}+\mathrm{H}_{2} \mathrm{O} \\
& \equiv \mathrm{Mn}^{\mathrm{IV}(\mathrm{III})}-(\mathrm{O}) \mathrm{SO}_{3}{ }^{-}+\mathrm{H}_{2} \mathrm{O} \\
& \rightarrow \equiv \mathrm{Mn}^{\mathrm{III}(\mathrm{II})}-\mathrm{OH}+\mathrm{SO}_{5}^{\cdot-}+\mathrm{H}^{+} \\
& \equiv \mathrm{Mn}^{\mathrm{III}(\mathrm{II})}-\mathrm{OH}+\mathrm{HSO}_{5}{ }^{-} \\
& \rightarrow \equiv \mathrm{Mn}^{\mathrm{III}(\mathrm{II})}-(\mathrm{O}) \mathrm{OSO}_{3}^{-}+\mathrm{H}_{2} \mathrm{O} \\
& \equiv \mathrm{Mn}^{\mathrm{III}(\mathrm{II})}-(\mathrm{O}) \mathrm{OSO}_{3}{ }^{-}+\mathrm{H}_{2} \mathrm{O} \\
& \rightarrow \equiv \mathrm{Mn}^{\mathrm{IV}(\mathrm{III})}-\mathrm{OH}+\mathrm{SO}_{4}^{\cdot-}+\mathrm{OH}^{-}
\end{aligned}
$$



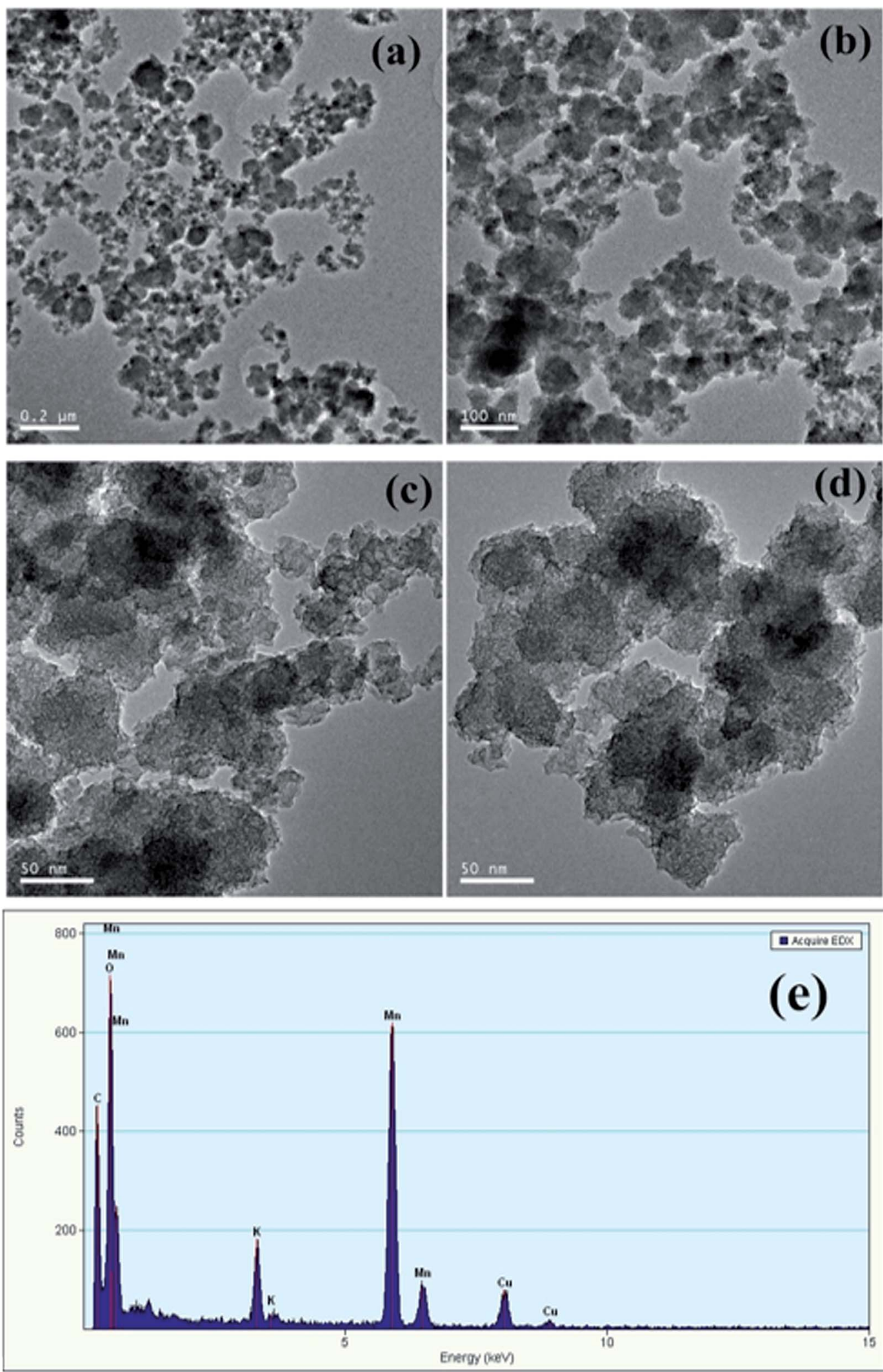

Fig. 7 TEM image of the solid samples $(a-d)$ and EDX spectra of the solid samples (e).

FTIR spectrometer was also used to observed the variations of WAS functional groups after conditioning in different conditions. As illustrated in Fig. 10, the broad absorption band from 3200 to $3400 \mathrm{~cm}^{-1}$ could be attributed to the stretching vibrations of $\mathrm{O}-\mathrm{H}$ group of polymeric substances. ${ }^{47}$ The peaks at 2925 and $2852 \mathrm{~cm}^{-1}$ were asymmetric and symmetric vibration of $\mathrm{CH}_{2}$ of aliphatic structures and lipids, respectively. ${ }^{48}$ The absorption band between 1640 to $1660 \mathrm{~cm}^{-1}$ was associated 


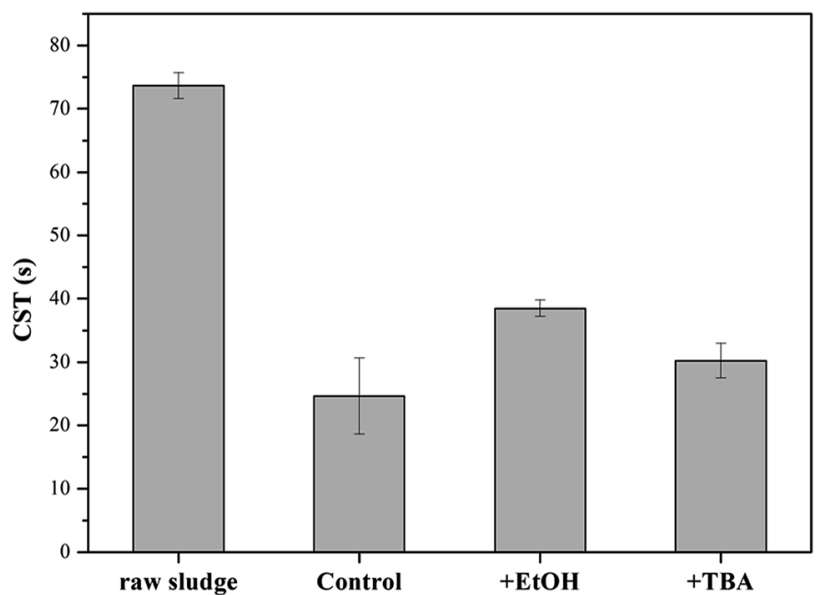

Fig. 8 Effect of EtOH and TBA on the dewaterability of the WAS samples by the $\mathrm{KMnO}_{4} / \mathrm{PMS}$ process (experimental conditions: $\left[\mathrm{KMnO}_{4}\right]+[\mathrm{PMS}]=4 \mathrm{mmol} \mathrm{g}^{-1} \mathrm{VSS}+3 \mathrm{mmol} \mathrm{g}^{-1} \mathrm{VSS},[\mathrm{EtOH}]=[\mathrm{TBA}]$ $=300 \mathrm{mmol} \mathrm{g}^{-1} \mathrm{VSS}, \mathrm{pH}_{0}=7, T=25^{\circ} \mathrm{C}$ ).

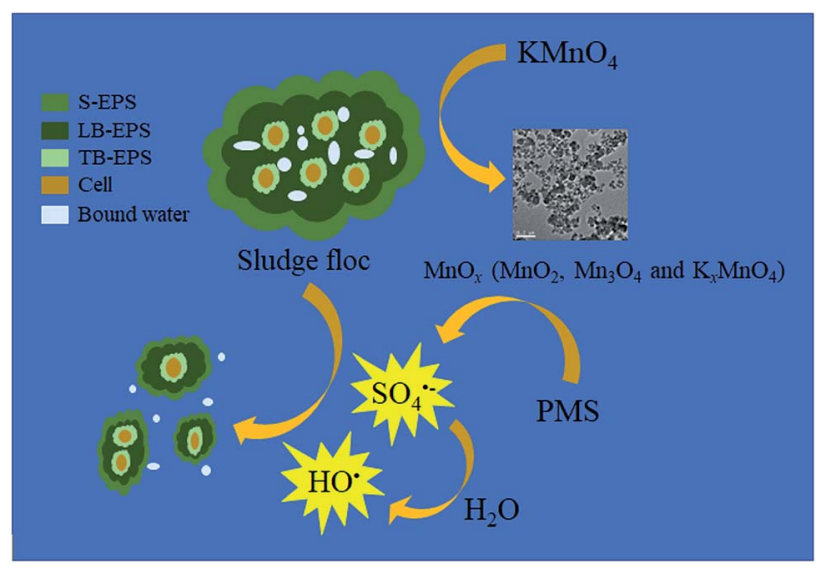

Fig. 9 Schematic diagram of PMS activation by $\mathrm{KMnO}_{4}$ during the sludge dewatering process.

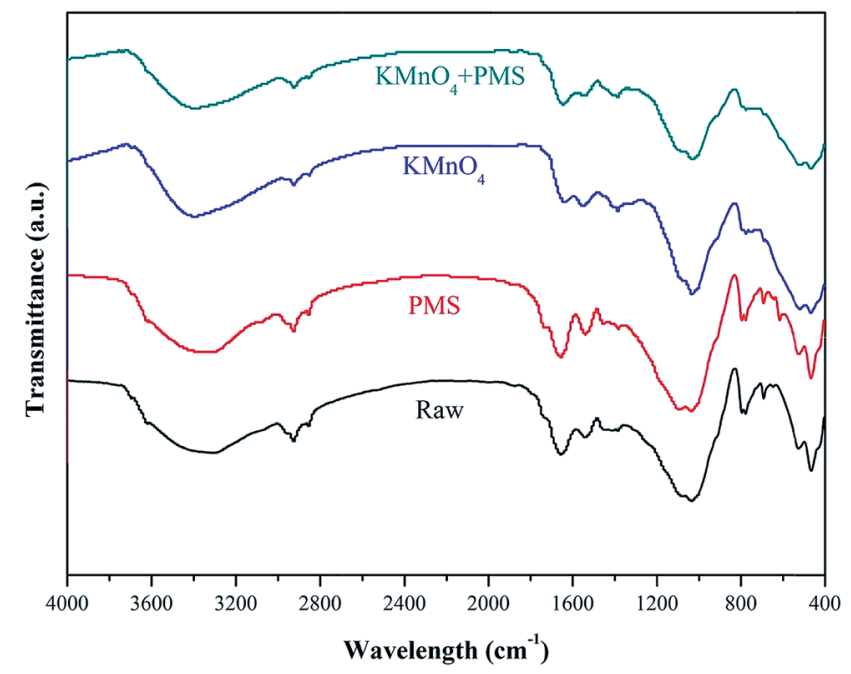

Fig. 10 FTIR spectra of the WAS samples treated at different conditions. with the stretching vibrations of $\mathrm{C}=\mathrm{O}$ and $\mathrm{C}-\mathrm{N}$, and $\mathrm{C}-\mathrm{N}$ stretching vibration and $\mathrm{N}-\mathrm{H}$ deformation vibration at 1550$1560 \mathrm{~cm}^{-1} .{ }^{49}$ The typical band located at $1040-1070 \mathrm{~cm}^{-1}$ was due to the stretching vibration of $\mathrm{OH}^{49}$ Besides, some peaks $\left(<1000 \mathrm{~cm}^{-1}\right)$ monitored in the "fingerprint" region could be attributed to the phosphate or sulfur functional groups, which is the functional groups for the production of nucleic acids. ${ }^{48}$ Compared with conditioning by $\mathrm{KMnO}_{4}$ or PMS alone, it can be clearly seen that the intensity of absorption bands of WAS decreased obviously after treatment by the $\mathrm{KMnO}_{4} / \mathrm{PMS}$ process, implying that $\mathrm{SO}_{4}{ }^{-}$and $\mathrm{HO}^{\circ}$ generated in the $\mathrm{KMnO}_{4} /$ PMS process could effectively degrade the proteins and polysaccharides in EPS and then resulted in the release of bound water and the improvement of sludge filterability.

\section{Conclusion}

This paper investigated the application of a combined use of $\mathrm{KMnO}_{4}$ and $\mathrm{PMS}\left(\mathrm{KMnO}_{4} / \mathrm{PMS}\right)$ for sludge dewatering. The major conclusions can be drawn as followed:

(1) Compared with the separate use of $\mathrm{KMnO}_{4}$ or PMS, the combined use of $\mathrm{KMnO}_{4}$ and $\mathrm{PMS}\left(\mathrm{KMnO}_{4} / \mathrm{PMS}\right)$ could significantly improve sludge dewaterability. After conditioning with the $\mathrm{KMnO}_{4} / \mathrm{PMS}$ process, CST of the WAS samples decreased from $73.65 \mathrm{~s}$ to $24.65 \mathrm{~s}$. However, the dewaterability of WAS would be worsened by conditioning with $\mathrm{KMnO}_{4}$ alone or PMS alone because the CST value increased significantly.

(2) The $\mathrm{KMnO}_{4} / \mathrm{PMS}$ process exerted significant effects on the physicochemical characteristics of the WAS samples. When the WAS samples were treated by the $\mathrm{KMnO}_{4} / \mathrm{PMS}$ process, both CST and $W_{\mathrm{C}}$ would decrease, the zeta potential was less negative, and the particle size would also decrease as the sludge flocs were broken into smaller fragments. Besides, the concentrations of protein and polysaccharide in EPS were also reduced due to the synergistic effect of $\mathrm{KMnO}_{4}$ and PMS.

(3) The combined use of TEM and EDX techniques verified the generation of $\mathrm{MnO}_{x}$ in the states of $\mathrm{MnO}_{2}, \mathrm{Mn}_{3} \mathrm{O}_{4}$ and $\mathrm{K}_{x} \mathrm{MnO}_{4}$ after $\mathrm{KMnO}_{4}$ oxidation. The radical scavenging experiments confirmed that the in situ generated $\mathrm{MnO}_{2}$ and $\mathrm{Mn}_{3} \mathrm{O}_{4}$ could activate $\mathrm{PMS}$ to generate $\mathrm{SO}_{4}{ }^{-}$and $\mathrm{HO}^{\circ}$, which were responsible for significantly enhanced sludge dewaterability. Moreover, the FTIR analysis further indicated that $\mathrm{SO}_{4}{ }^{-}$and $\mathrm{HO}^{\circ}$ generated in the $\mathrm{KMnO}_{4} / \mathrm{PMS}$ process could improve sludge dewaterability.

\section{Conflicts of interest}

There are no conflicts to declare.

\section{Acknowledgements}

This work was financially supported by the Fund of State Key Laboratory of Pollution Control and Resource Reuse (PCRRF17023). 


\section{References}

1 D.-Q. He, L.-F. Wang, H. Jiang and H.-Q. Yu, Chem. Eng. J., 2015, 272, 128-134.

2 M. S. Kim, K. M. Lee, H. E. Kim, H. J. Lee, C. Lee and C. Lee, Environ. Sci. Technol., 2016, 50, 7106-7115.

3 H. Yuan, N. Zhu and L. Song, Bioresour. Technol., 2010, 101, 4285-4290.

4 J. Liu, Q. Yang, D. Wang, X. Li, Y. Zhong, X. Li, Y. Deng, L. Wang, K. Yi and G. Zeng, Bioresour. Technol., 2016, 206, 134-140.

5 K.-M. Lee, M. S. Kim and C. Lee, Sustainable Environ. Res., 2016, 26, 177-183.

6 W. Yu, J. Yang, S. Tao, Y. Shi, J. Yu, Y. Lv, S. Liang, K. Xiao, B. Liu, H. Hou, J. Hu and X. Wu, Water Res., 2017, 126, 342-350.

7 R. Mo, S. Huang, W. Dai, J. Liang and S. Sun, Chem. Eng. J., 2015, 269, 391-398.

8 C. Bougrier, J. P. Delgenès and H. Carrère, Chem. Eng. J., 2008, 139, 236-244.

9 X. Feng, J. Deng, H. Lei, T. Bai, Q. Fan and Z. Li, Bioresour. Technol., 2009, 100, 1074-1081.

10 K. Hu, J. Q. Jiang, Q. L. Zhao, D. J. Lee, K. Wang and W. Qiu, Water Res., 2011, 45, 5969-5976.

11 C.-J. Cheng and P. K. A. Hong, Bioresour. Technol., 2013, 142, 69-76.

12 G. Y. Zhen, X. Q. Lu, Y. Y. Li and Y. C. Zhao, Bioresour. Technol., 2013, 136, 654-663.

13 P. Shi, R. Su, S. Zhu, M. Zhu, D. Li and S. Xu, J. Hazard. Mater., 2012, 229-230, 331-339.

14 J. Yu, K. Xiao, J. Yang, W. Yu, K. Pei, Y. Zhu, J. Wang, S. Liang, J. Hu, H. Hou and B. Liu, ACS Sustainable Chem. Eng., 2019, 7, 324-331.

15 E. Neyens, J. Baeyens, M. Weemaes and B. De heyder, J. Hazard. Mater., 2003, 98, 91-106.

16 H. Zhang, J. Yang, W. Yu, S. Luo, L. Peng, X. Shen, Y. Shi, S. Zhang, J. Song, N. Ye, Y. Li, C. Yang and S. Liang, Water Res., 2014, 59, 239-247.

17 Y. Li, X. Yuan, D. Wang, H. Wang, Z. Wu, L. Jiang, D. Mo, G. Yang, R. Guan and G. Zeng, Bioresour. Technol., 2018, 262, 294-301.

18 K. Xiao, Y. Chen, X. Jiang, Q. Yang, W. Y. Seow, W. Zhu and Y. Zhou, Water Res., 2017, 109, 13-23.

19 T. K. Lau, C. Wei and N. J. D. Graham, Environ. Sci. Technol., 2007, 41, 613.

20 G. Ying-Hong, M. Jun, L. Xu-Chun, F. Jing-Yun and C. Li-Wei, Environ. Sci. Technol., 2011, 45, 9308.

21 C. Tan, N. Gao, Y. Deng, N. An and J. Deng, Chem. Eng. J., 2012, 203, 294-300.

22 J. Deng, Y. Shao, N. Gao, Y. Deng, S. Zhou and X. Hu, Chem. Eng. J., 2013, 228, 765-771.

23 O. S. Furman, A. L. Teel and R. J. Watts, Environ. Sci. Technol., 2010, 44, 6423-6428.
24 C. Qi, X. Liu, J. Ma, C. Lin, X. Li and H. Zhang, Chemosphere, 2016, 151, 280-288.

25 G. P. Anipsitakis and D. D. Dionysiou, Environ. Sci. Technol., 2004, 38, 3705-3712.

26 J. Deng, Y. Ge, C. Tan, H. Wang, Q. Li, S. Zhou and K. Zhang, Chem. Eng. J., 2017, 330, 1390-1400.

27 J. Cui, L. Zhang, B. Xi, J. Zhang and X. Mao, Chem. Eng. J., 2017, 313, 815-825.

28 C. Wu, G. Zhang, P. Zhang and C.-C. Chang, Chem. Eng. J., 2014, 240, 420-425.

29 T. Niu, Z. Zhou, W. Ren, L.-M. Jiang, B. Li, H. Wei, J. Li and L. Wang, Int. Biodeterior. Biodegrad., 2016, 106, 170-177.

30 J. Yang, X. Liu, D. Wang, Q. Xu, Q. Yang, G. Zeng, X. Li, Y. Liu, J. Gong and J. Ye, Water Res., 2019, 148, 239-249.

31 B. Fr/olund, T. Griebe and P. H. Nielsen, Appl. Microbiol. Biotechnol., 1995, 43, 755-761.

32 M. DuBois, K. A. Gilles, J. K. Hamilton, P. A. Rebers and F. Smith, Anal. Chem., 1956, 28, 350-356.

33 K. Xiao, Y. Chen, X. Jiang, V. K. Tyagi and Y. Zhou, Water Res., 2016, 105, 470-478.

34 C. Cai, H. Zhang, X. Zhong and L. Hou, J. Hazard. Mater., 2015, 283, 70-79.

35 J. Yan, M. Lei, L. Zhu, M. N. Anjum, J. Zou and H. Tang, J. Hazard. Mater., 2011, 186, 1398-1404.

36 J. Liu, Z. Zhao, P. Shao and F. Cui, Chem. Eng. J., 2015, 262, 854-861.

37 J. Liu, Y. Wei, K. Li, J. Tong, Y. Wang and R. Jia, Water Res., 2016, 90, 225-234.

38 G. Zhen, X. Lu, B. Wang, Y. Zhao, X. Chai, D. Niu, A. Zhao, Y. Li, Y. Song and X. Cao, Bioresour. Technol., 2012, 124, 29-36.

39 H. Gharibi, M. H. Sowlat, A. H. Mahvi, M. Keshavarz, M. H. Safari, S. Lotfi, M. Bahram Abadi and A. Alijanzadeh, Chemosphere, 2013, 90, 1487-1494.

40 G. Zhen, X. Lu, Y. Li, Y. Zhao, B. Wang, Y. Song, X. Chai, D. Niu and X. Cao, Bioresour. Technol., 2012, 119, 7-14.

41 M. J. Higgins and J. T. Novak, Water Environ. Res., 1997, 69, 215-224.

42 D. Mowla, H. N. Tran and D. G. Allen, Biomass Bioenergy, 2013, 58, 365-378.

43 K. A. M. Ahmed, Journal of Taibah University for Science, 2016, 10, 412-429.

44 E. Saputra, S. Muhammad, H. Sun, H. M. Ang, M. O. Tadé and S. Wang, Environ. Sci. Technol., 2013, 47, 5882-5887.

45 E. Saputra, S. Muhammad, H. Sun, H.-M. Ang, M. O. Tadé and S. Wang, J. Colloid Interface Sci., 2013, 407, 467-473.

46 Z. Zhao, J. Zhao and C. Yang, Chem. Eng. J., 2017, 327, 481489.

47 Z. Chen, W. Zhang, D. Wang, T. Ma, R. Bai and D. Yu, Water Res., 2016, 103, 170-181.

48 H.-y. Pei, W.-r. Hu and Q.-h. Liu, J. Hazard. Mater., 2010, 178, 397-403.

49 J. Laurent, M. Casellas, H. Carrere and C. Dagot, Chem. Eng. J., 2011, 166, 841-849. 